\section{PENINGKATAN PENGETAHUAN \\ MASYARAKAT \\ PENGELOLAAN PEMBUANGAN \\ DAN PEMILAHAN SAMPAH \\ RUMAH TANGGA DI \\ KELURAHAN KALIGANDU KOTA SERANG}

\author{
Siska Mardiana ${ }^{1}$, Rethorika Berthanila ${ }^{2}$, \\ Marthalena ${ }^{3}$, Muhammad Ryan Rasyid ${ }^{4}$ \\ Prodi Ilmu Komunikasi FISIPKUM \\ Universitas Serang Raya ${ }^{1}$ \\ Prodi Administrasi Negara FISIPKUM \\ Universitas Serang Raya ${ }^{2}$ \\ Prodi Ilmu Komunikasi FISIPKUM \\ Universitas Serang Raya ${ }^{3}$ \\ Prodi Manajemen Fakultas Ekonomi dan \\ Bisnis Universitas Serang Raya ${ }^{4}$
}

${ }^{*}$ Corresponding Author

Email : mardiana.siska@yahoo.com
Abstrak

Sampah merupakan salah satu permasalahan lingkungan yang memerlukan penanganan serius. Permasalahan yang dihadapi mitra pengabdian, yaitu terletak pada minimnya pengetahuan mengenai menjaga kebersihan lingkungan terutama membuang sampah, dan kurangnya fasilitas pendukung. Berangkat dari permasalahan tersebut, pengabdian ini berusaha menanggulangi masalah melalui kegiatan peningkatan pengetahuan mengenai pentingnya menjaga kebersihan lingkungan, pemilahan sampah organic dan anorganik dan memberikan bantuan penyedian fasilitas tong sampah. Tujuan kegiatan pengabdian ini memberikan pengetahuan kepada masyarakat megenai pengelolaan pembuangan dan pemilahan sampah rumah tangga. Adapun metode pelaksanaan yang dilakukan dalam kegiatan ini adalah melalui tahap sosialisasi dan perizinan, tahap persiapan dan tahap evaluasi. Hasilnya adanya peningkatan pemahaman di masyarakat mengenai pentingnya menjaga kebersihan lingkungan, tidak membuang sampah sembarangan, memilah sampah organik dan anorganik.

Kata kunci : Pengelolaan, pembuangan dan pemilahan sampah,

\section{Abstract}

Garbage is one of the environmental problems that requires serious handling. The problem faced by the service partners, which is located in the lack of knowledge about maintaining environmental cleanliness, especially disposing of garbage, and the lack of supporting facilities. Departing from these problems, this service seeks to overcome the problem through increasing knowledge about the importance of maintaining environmental cleanliness, sorting organic and inorganic waste and providing assistance in the provision of trash cans facilities. The purpose of this community service activity is to provide knowledge to the community regarding the management of household waste disposal and sorting. The method of implementation carried out in this activity are: the stage of socialization and licensing, the stage of preparation and evaluation stage. The result is an increased understanding in the community about the importance of maintaining environmental cleanliness, not littering, sorting out organic and inorganic waste.

Keywords: Waste management, disposal and sorting 


\section{PENDAHULUAN}

Sampah merupakan salah satu permasalahan lingkungan yang memerlukan penanganan serius. Berdasarkan Undang-Undang No. 18 Tahun 2008 pasal 1, sampah adalah sisa kegiatan sehari-hari manusia dan atau proses alam yang berbentuk padat. Secara umum sampah dibedakan menjadi tiga, yaitu sampah organik/basah, sampah anorganik/kering, dan sampah berbahaya (Sejati, 2009: 15). Sampah organik adalah jenis sampah yang dihasilkan organisme hidup sehingga mudah membusuk dan mudah diuraikan sementara sampah anorganik adalah jenis sampah yang tidak mudah membusuk dan tidak mudah diuraikan dan sampah berbahaya adalah limbah dari bahan bahan berbahaya dan beracun seperti limbah rumah sakit, dan limbah pabrik

Sampah akan bertambah seiring dengan meningkatnya jumlah penduduk di suatu wilayah. Pola konsumsi masyarakat ikut memberi kontribusi dalam peningkatan volume sampah yang semakin beragam jenisnya. Sampah rumah tangga merupakan salah satu sumber sampah yang cukup besar peranannya dalam peningkatan volume sampah di suatu lingkungan (Suparmini, 2013). Sampah dihasilkan oleh semua aktivitas manusia, baik dari proses industri, rumah sakit, pariwisataperhotelan, dan juga dari rumah tangga yang merupakan pemasok sampah terbesar di daerah pemukiman. Manusia dalam aktivitasnya hanya memanfaatkan sumber daya alam yang berasal dari lingkungan dan mengembalikan sisa hasil aktivitas (sampah) kembali lagi organik (Sukesi, dkk : 2017).

Kecamatan Serang merupakan penghasil sampah terbanyak di Kota Serang yaitu sebanyak 113,2 ton berdasarkan data dari Dinas Lingkungan Hidup Kota Serang. Sebanyak 360 ton sampah dihasilkan setiap harinya di Kota Serang, namun hanya sekitar 70 sampai 80 ton saja yang bisa diangkut oleh petugas kebersihan Pemkot Serang ke Tempat Pembuangan Sampah Akhir (TPSA) sampah di Cilowong (Republika.co.id).

Salah satu Kelurahan yang termasuk dalam wilayah Kecamatan Serang adalah Kelurahan Kaligandu. Kelurahan Kaligandu terdiri dari 76 RT 
dan 19 RW, dengan jumlah penduduk sebanyak 21.357 jiwa yang terdiri dari laki laki 10.813 jiwa dan perempuan 10.544 jiwa. Kegiatan pengabdian ini dilakukan di RW 11 Link Ciputat dan meliputi 3 Rukun Tetangga yaitu RT01, RT02, dan RT03. Lokasi ketiga RT ini dari jalan raya utama cukup dekat, tapi begitu memasuki wilayah ini terlihat suasana rumah rumah yang cukup padat, dengan akses jalan gang, dan kebersihan jalan yang kurang dijaga. Link Ciputat RW 11 ini terdiri dari sekitar 700 kartu keluarga terdaftar, dengan mayoritas penduduk bekerja sebagai pedagang, dikarenakan dekat dengan Kota dan Pasar Induk. Warganya terdiri dari sekitar tujuh puluh persen pendatang.

Hasil observasi awal, secara umum lingkungan di RW 11 ini terlihat kurang menjaga kebersihan lingkungan, yaitu tidak adanya tempat pembuangan sampah di sekitar rumah warga, mereka membuang sampah dimana saja, walaupun ada di beberapa rumah tempat sampah tapi belum melakukan pemisahan sampah organik dan anorganik karena keterbatasan pengetahuan mereka, sehingga jika dibiarkan lingkungan yang tidak sehat juga akan mengganggu kesehatan warga.

Penanganan sampah yang kurang optimal akan menimbulkan berbagai permasalahan lingkungan, seperti timbulnya banjir, timbulnya penyakit, sanitasi lingkungan memburuk, turunnya kandungan organik lahan pertanian, dan mempercepat terjadinya pemanasan global. Oleh karena itu diperlukan adanya komitmen bersama dalam pengelolaan sampah sehingga tidak menimbulkan berbagai permasalahan lingkungan (Tamyiz,dkk : 2018). Melalui Pelatihan pengelolaan sampah menjadi salah satu sumber informasi yang dapat membuat masyarakat tertarik untuk memahami dan melakukan pengelolaan sampah (Latifatul, dkk :2018)

Dengan memperhatikan dan mempertimbangkan kondisi dan situasi disekitar Link Ciputat ini, maka kami memandang perlu diadakannya kegiatan pengabdian ini dengan melibatkan mahasiswa dan warga, yaitu kegiatan penyuluhan mengenai peningkatan pengetahuan pentingnya menjaga lingkungan, dan pemberian tong sampah kepada warga. 
Melalui observasi, survey lapangan dan wawancara dengan mitra kegiatan pengabdian, diketahui beberapa permasalahan yang ada diantaranya yaitu:

a. Belum teratur dan terkoordinirnya nya mengenai pembuangan sampah.

b. Rendahnya kepedulian warga mengenai kebersihan lingkungan

c. Kurang tersedianya fasilitas tong tong pembuangan sampah di lingkungan.

d. Belum adanya pemisahan sampah organik dan anorganik

Berdasarkan uraian analisis situasi dan dengan mempertimbangkan masalah yang dihadapi mitra pengabdian, dapat diketahui bahwa titik berat masalah mitra pengabdian terletak pada minimnya pengetahuan mengenai menjaga kebersihan lingkungan terutama pembuang sampah, dan kurangnya fasilitas pendukung. Untuk menanggulangi hal tersebut, maka pengabdiannya berusaha menanggulangi masalah melalui kegiatan penyuluhan peningkatan pengetahuan mengenai pentingnya menjaga kebersihan lingkungan, bantuan penyedian fasilitas tong sampah.

\section{METODE PELAKSANAAN}

Kegiatan pengabdian ini menggunakan metode penyuluhan mengenai pentingnya menjaga kebersihan lingkungan dan bantuan penyediaan fasilitas tong sampah ini terdiri atas beberapa tahapan, yaitu sosialisasi dan perijinan, persiapan penyuluhan dan pelatihan pendampingan, pelaksanaan penyuluhan dan pelatihan pendampingan serta evaluasi.

Tahapan awal pada kegiatan pengabdian ini adalah tahap sosialisasi dan perijinan. Pada tahapan ini, kami melakukan observasi dimasyarakat mengenai permasalahan yang ada, kemudian mendiskusikannya dengan Bapak RW 11 Kelurahan Kaligandu dikediamannya, yang dihadiri oleh beberapa warga serta meminta ijin bahwa akan diadakan kegiatan tersebut.

Tahap selanjutnya adalah tahapan persiapan penyuluhan dan pelatihan pendampingan. Pada tahap persiapan ini, kami mendiskusikan tentang berbagai kebutuhan alat dan bahan yang dibutuhkan dan menyiapkan 
pengadaannya, juga berkoordinasi dengan Ketua RW 11, dan Ketua RT 01, Ketua RT02 dan Ketua RT03 untuk persiapan tempat dan waktu pelaksanaan kegiatan, kemudian dilanjutkan dengan tahapan pelaksanaan penyuluhan dan pelatihan pendampingan.

Tahapan ini dilakukan melalui metode penyampaian materi dan diskusi. Materi yang disampaikan dalam kegiatan penyuluhan ini mencakup: penyampaian materi mengenai pentingnya kebersihan lingkungan dan pemilahan sampah; strategi memilih lokasi tempat pengolahan sampah yang tepat; penyediaan prasarana dan sarana; pemilahan sampah serta pemeliharaan prasarana dan sarana pengolahan sampah. Pada kegiatan penyuluhan ini juga dilakukan sesi tanya jawab dengan masyarakat sasaran, dan diberikan tong sampah yang terdiri dari tong sampah untuk sampah organik dan untuk sampah anorganik.

Praktik dan Pendampingan Pengolahan Sampah Kegiatan pelatihan pengolahan sampah dimulai dari pemilihan lokasi kegiatan, pelatihan pemilahan sampah organik dan anorganik, pengontrolan pengolahan sampah, dan pelatihan pemeliharaan prasarana dan sarana pengolahan sampah. Pelatihan dan praktik pengolahan sampah ini dilakukan dengan metode partisipasi aktif. Lokasi yang dipilih berdasarkan pengamatan dan kesadaran warga akan pentingnya kesadaran lingkungan yang lebih sehat dan tertata. Pelatihan praktik pengolahan sampah dilakukan dengan metode demontarsi dan praktik langsung oleh kelompok masyarakat sasaran. Pada kegiatan praktik ini, seluruh kelompok masyarakat sasaran dilatih dalam memilah sampah organik dan anorganik.

Selain praktik dan pendampingan pengolahan sampah, Tahap terakhir adalah evaluasi. Tahap evaluasi yang dilakukan dalam kegiatan ini meliputi: kehadiran dan keaktifan anggota kelompok masyarakat sasaran, tingkat pengetahuannya, dan evaluasi keberlanjutan kegiatan. 


\section{HASIL DAN PEMBAHASAN}

Kegiatan pengabdian ini dilakukan di RW 11 Kelurahan Kaligandu, yang melibatkan mahasiswa dan dihadiri oleh mitra yaitu warga sebanyak 43 orang, yaitu 16 orang laki laki dan 27 orang perempuan. Peserta yang hadir merupakan mitra kegiatan pengabdian masyarakat, mereka terlihat antusias mengikuti kegiatan, aktif bertanya dan berdiskusi. Adapun jadwal kegiatan kami sajikan pada tabel 1.

Tabel 1

Jadwal Kegiatan

\begin{tabular}{|c|c|c|c|c|}
\hline \multirow[t]{2}{*}{ No } & \multirow[t]{2}{*}{ Jenis Kegiatan } & \multicolumn{3}{|c|}{ Bulan } \\
\hline & & Mei & Juni & Juli \\
\hline 1 & Tahap Sosialisasi dan & & & \\
\hline & Perijinan & & & \\
\hline 2 & Tahap Persiapan & & & \\
\hline 3 & Tahap Pelaksanaan & & & \\
\hline 4 & Tahap Evaluasi & & & \\
\hline
\end{tabular}

Untuk pencapaian hasil tempat sampah, termasuk pemahaman

kegiatan, kami uraikan berdasarkan tahapan yang kami lakukan, yaitu :

a. Tahap sosialiasi dan perizinan

Pada tahap awal kegiatan, ada dua agenda utama yang dilakukan tim yaitu (1) observasi dan survey lapangan; (2) sosialisasi dan perizinan. Kegiatan observasi dan survey lapangan dilakukan di bulan Mei dihari sabtu dan Minggu, tim berkeliling melihat lingkungan sekitar dan menemukan kondisi lingkungan yang tidak bersih, banyak sampah dan banyak warga yang tidak memiliki pemilahan sampah organik dan anorganik. Tim juga mendatangi warga dan berbincang, lalu didapat informasi bahwa untuk pembuangan sampah ada yang membuang kemana saja karena kurang terkoordinir.

$$
\text { Kegiatan sosialisasi dan }
$$
perizinan juga dilakukan di bulan Mei, yaitu tim mendatangi kediaman Bapak RW 11, kami menyampaikan hasil observasi kami, dan rencana untuk mengadakan kegiatan penyuluhan dan pendampingan. Setelah ketua RW 
menyetujui, dan memberikan ijin untuk diadakan dilapangan dekat rumah Pak RW, maka tim melanjutkan tahap selanjutnya yaitu tahap persiapan.

b. Tahap Persiapan

Pada tahap ini, dilakukan pada bulan Juni, tim mempersiapkan alat dan bahan yang dibutuhkan untuk kegiatan penyuluhan dan pendampingan. Untuk kegiatan penyuluhan peningkatan pengetahuan menjaga kebersihan lingkungan, tim menyediakan total 42 drum sampah. Drum sampah ini lalu di cat dengan warna kuning dan ada yang warna biru, kemudian dibuatkan tiang untuk dudukan. Pembuatan tong sampah sendiri dibuat oleh tim dengan menggunakan material besi dangan metode pembuatan tiang las agar tong sampah kuat sekaligus pemasangan tong menggunakan metode cor semen, banyak sekali laporan yang masuk jika tong sampah yang ada seringkali hilang, maka dari itu kami memasang tong sampah ke tanah lalu di cor untuk menghindari kehilangan tong kembali. Selain itu untuk kegiatan penyuluhan Tim juga mempersiapkan slide materi yang akan disampaikan kepada warga, dan mencetaknya untuk dibagikan kepada warga.

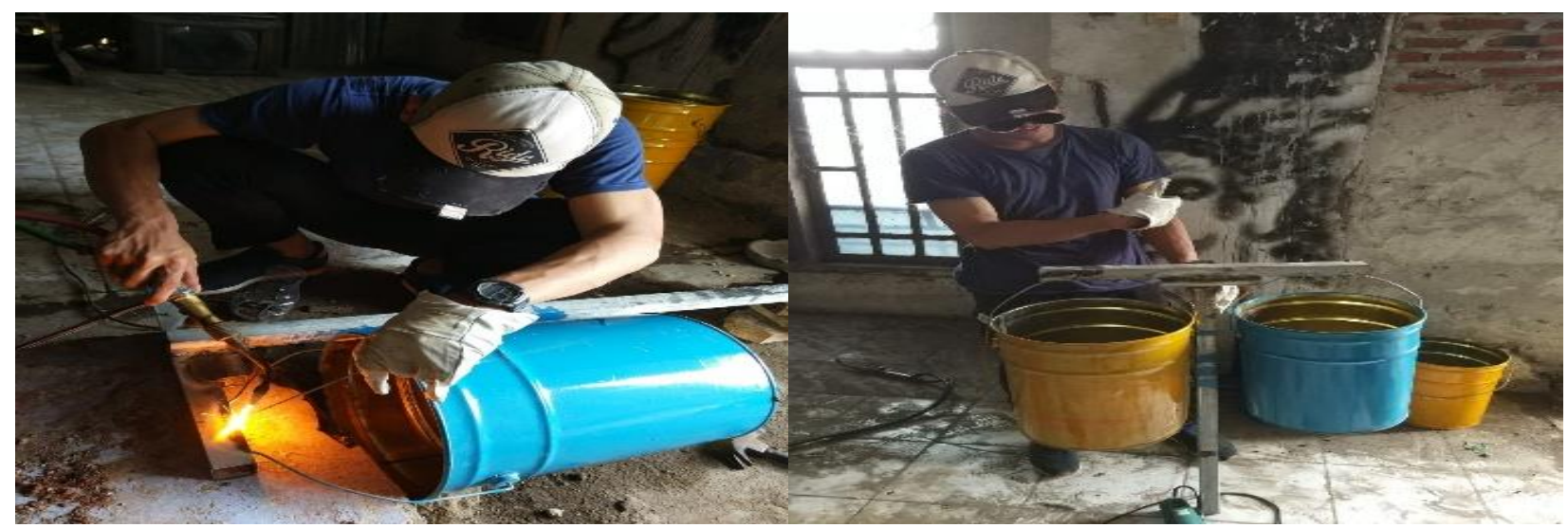

Gambar 1

Kegiatan tahap persiapan mengecat dan membuat pegangan tong sampah 
c. Tahap Pelaksanaan

Tahap pelaksanaan adalah kegiatan penyuluhan dan kegiatan pendampingan kepada mitra yaitu warga RW11 Kelurahan Kaligandu. Kegiatan ini dilaksanakan pada awal bulan Juli 2019 selama dua hari. Pelaksanaan diawali dengan pemasangan tenda dilapangan dan penataan bangku untuk tempat kegiatan penyuluhan, kemudian dipersiapkan juga alat dan bahan dan drum sampah yang sudah dimodifikasi.

Selanjutnya kegiatan penyuluhan di mulai dengan pemberian materi mengenai pentingnya pengelolaan sampah rumah tangga, dan pemilahan sampah organik dan anorganik.
Warga yang datang tampak antusias dengan mengajukan banyak pertanyaan sehingga sesi diskusi menjadi menarik, materi juga dibagikan dalam bentuk cetak. Materi dilanjutkan esok harinya dengan pemberian drum sampah kepada ketua RW 11 Kelurahan Kaligandu, dan dilanjutkan dengan pemasangan drum yang ditanam didalam tanah sehingga tidak terjadi lagi kehilangan drum sampah, masing masing RT menerima dua pasang drum untuk sampah organic dan anorganik kepada RT01, RT02 dan RT 03. Selain itu juga drum sampah diberikan kepada sekolah sekolah, madarasah dan masjid melalui Ketua RW11.

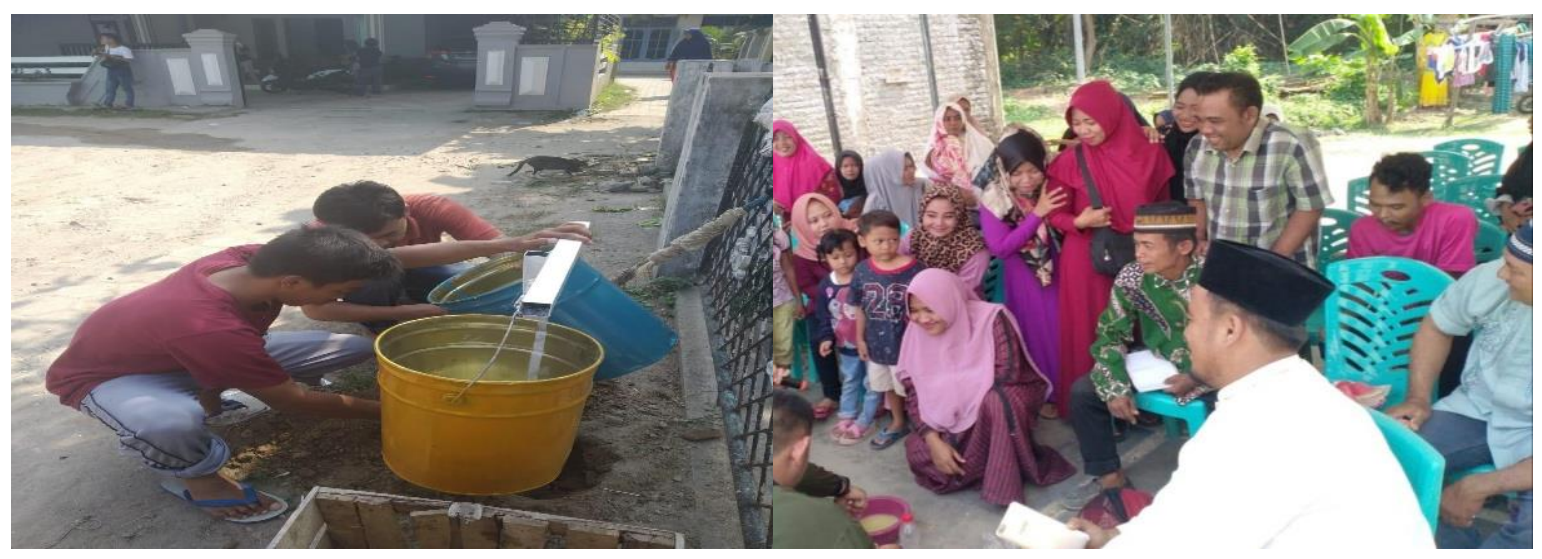

Gambar 2

Tahap Pelaksanaan Penyuluhan dan Pemasangan Tong Sampah 
d. Tahap Evaluasi

Tahap terakhir dari

keseluruhan kegiatan pengabdian ini

adalah melakukan evaluasi kegiatan.

Tim melihat dari kehadiran warga

yang cukup banyak mulai dari

pelatihan serta penyuluhan dan

pemasangan drum sampah. Selain itu

tim juga wawancara dengan beberapa

warga tentang pelaksanaan kegiatan,

dan hasilnya warga merasa cukup

puas, mereka jadi lebih tahu mengenai

kebersihan lingkungan dan pemilahan

sampah.

\section{PENUTUP}

\section{Kesimpulan}

Beberapa hal yang dapat

disimpulkan dari keseluruhan hasil

kegiatan kemitraan ini antara lain:

1. Secara keseluruhan program telah berjalan $100 \%$, artinya semua tahap kegiatan kemitraan telah dilakukan dengan sebaik-baiknya mulai dari tahap awal hingga tahap akhir.

2. Adanya peningkatan pemahaman di masyarakat mengenai pentingnya menjaga kebersihan lingkungan, tidak membuang sampah sembarangan, memilah sampah organik dan anorganik. 


\section{REFERENSI}

Latifatul, dkk. 2018. Pengaruh Sosialisasi Pemilahan Sampah Organik dan Non Organik Serta Manajemen Sampah Terhadap Penurunan Volume Sampah di Dusun Krajan Desa Kemuningsari Lor Kecamatan Panti Kabupaten Jember. The Indonesian Journal of Health Science. Edisi Khusus

Sejati, Kuncoro. 2009. Pengolahan Sampah Terpadu. Yogyakarta: Kanisius

Sukesi, dkk. 2017. Pemberdayaan Masyarakat dalam Pengelolaan Sampah Rumah Tangga. Proceeding. UAD Press: Yogyakarta

Suparmini, dkk. 2013. Pelatihan Pengelolaan Sampah Rumah Tangga dengan Metode Komposting di Desa Banyurejo Kecamatan Tempel Kabupaten Sleman. Laporan Kegiatan Pengabdian pada Masyarakat, UNY: Yogyakarta

Tamyiz, dkk. 2018. Pelatihan Pengelolaan Sampah Rumah Tangga di Desa Kedungsumur Kecamatan Krembung Kabupaten Sidoarjo. Journal Of Science and Sosial Development. Vol 1 No 1

Undang Undang Nomor 18 Tahun 2008 Tentang Pengelolaan Sampah

Dokumen

Data Demografi Kelurahan Kaligandu

Internet

https://nasional.republika.co.id/berita/nas ional/jabodetabeknasional/ptch0x384/pemkot-serang- kesulitan-tangani-sampah diakses pada 14 september 2019 